\title{
ASSOCIATION BETWEEN SLEEP QUALITY AND LIFESTYLE HABITS OF COLLEGE STUDENTS
}

\author{
Monique Araujo ${ }^{1}$, Bruna Turi-Lynch ${ }^{1}$, Rômulo Fernandes ${ }^{2}$, Jamile Codogno ${ }^{2}$, Everton Zanuto ${ }^{1}$ \\ ${ }^{1}$ Universidade do Oeste Paulista - UNOESTE, Presidente Prudente, SP. ${ }^{2}$ Universidade Estadual Paulista - UNESP, \\ Presidente Prudente, SP. e-mail: everton@unoeste.br
}

\begin{abstract}
The aim of this study was to verify sleep quality, as well as its determinants, among college students of a private university in Brazil. The sample consisted of 303 college students. Sleep quality was assessed by the Mini-sleep Questionnaire, and other variables included current physical activity, previous physical activity, sedentary behavior, body mass index, alcohol consumption, smoking, and employment. We found a significant association between bad sleep quality and body mass index $(p=0.001)$, alcohol consumption $(p=0.001)$, smoking $(p=0.005)$ and employment $(p=0.030)$. However, having a job was considered a protective factor for bad sleep quality (OR=0.66 [0.40;0.98]), regardless of other factors. College students present a high prevalence of altered sleep, having as determinants alcohol consumption, smoking, overweight, and obesity. On the other hand, being employed was shown to be a protective factor for bad sleep quality.
\end{abstract}

Keywords: Sleep disorders, lifestyle, quality of life, obesity, smoking.

\section{ASSOCIAÇÃO ENTRE QUALIDADE DO SONO E HÁBITOS DE VIDA DE ESTUDANTES UNIVERSITÁRIOS}

\section{RESUMO}

O objetivo deste estudo foi verificar a qualidade do sono, bem como seus determinantes, em universitários de uma universidade privada no Brasil. A amostra foi composta por 303 estudantes universitários. A qualidade do sono foi avaliada pelo Mini-Sleep Questionnaire, e outras variáveis incluíram atividade física atual, atividade física prévia, comportamento sedentário, índice de massa corporal, consumo de álcool, tabagismo e informações sobre atividade laboral. Encontrou-se associação significativa entre má qualidade do sono e índice de massa corporal $(p=0,001)$, consumo de álcool $(p=0,001)$, tabagismo $(p=0,005)$ e atividade laboral $(p=0,030)$. Porém, realizar atividade laboral foi considerado fator de proteção para a má qualidade do sono $(\mathrm{OR}=0,66[0,40 ; 0,98])$, independentemente dos demais fatores. Estudantes universitários apresentam alta prevalência de sono alterado, tendo como determinantes o consumo de álcool, tabagismo, sobrepeso e obesidade. Por outro lado, estar empregado mostrou-se fator protetor para a má qualidade do sono.

Palavras-chave: Distúrbios do sono, estilo de vida, qualidade de vida, obesidade, tabagismo.

\section{INTRODUCTION}

Sleep quality is essential for humans' health due to its restorative function, energy conservation, and protection ${ }^{1}$. For adults, the recommendation of sleep duration is at least seven uninterrupted hours per night $^{2}$. Sleeprelated disorders (SRD) are associated with the individual's lifestyle, being mediated by biological, social and environmental factors, as well as physical and mental health ${ }^{3}$. SRD are 
characterized by symptoms of insomnia, excessive daytime sleepiness, inability to sleep when desired and abnormalities during sleep ${ }^{1}$.

It is estimated that the prevalence of SRD in the United States is $42 \%{ }^{4}$, whereas in Brazil is $46.7 \%{ }^{5}$. These data draw attention and concern, given the fact that harmful health changes due to SRD tend to be chronic ${ }^{6}$. In this sense, the identification of groups at greater risk for the development of SRD is a relevant factor in health policies. Among the general population, college students are more likely to develop such disorders ${ }^{7}$.

A United States study including more than 7,600 college students found a significant proportion ( $65 \%)$ of participants reporting insufficient hours of sleep per night (lower than recommended), and approximately one-third of respondents rated their sleep quality as poor ${ }^{7}$. Deterioration of sleep quality among college students is associated with changes in behavioral habits that occur in this period, such as alcohol consumption, smoking, weight gain and even a decrease in physical activity practice ${ }^{8-11}$.

Recent literature has shown that the risk factors mentioned above are associated with insomnia ${ }^{12}$, disturbed sleep ${ }^{9}$, decreased efficiency and sleep duration ${ }^{13}$. Additionally, irregular sleep patterns may interfere with academic performance ${ }^{7}$, accounting for $1.2 \%$ of the worst grades among college students ${ }^{14}$.

However, despite its importance, there are still limited studies in Brazil addressing the quality of sleep in college students, as well as their determinants. It is necessary to emphasize the need for national research that investigates this subject to support the implementation of educational and health promotion programs for college students, aiming to minimize risk factors and consequently improving the quality of life and academic performance. Thus, the objective of this study was to verify sleep quality, as well as its determinants, among college students of a private university in Brazil.

\section{METHODOLOGY}

Sample selection

The sample was composed of college students (freshmen and seniors) of 25 undergraduate programs. This university has the largest number of students in the western region of the São Paulo state $(16,333$ students in 56 incampus programs and 8 online programs) and receives students from different cities. The project was conducted in the city of Presidente Prudente ( 210,000 inhabitants), the largest city in the West part of the São Paulo State, with a high human development index (0.806).

College students were approached by the researchers in the classroom and invited to participate in the research. Those who voluntarily agreed to take part in the study signed the consent form and filled out questionnaires. The study was approved by the Research Ethics Committee of the Universidade do Oeste Paulista - UNOESTE (CAAE: 18653813.2.0000.5515).

The inclusion criterion was defined as being officially registered at the university and classified as a freshman or senior in an undergraduate program. The minimum sample size was calculated considering the number of students enrolled in the university $(16,333)$, and sample error of $5 \%$. This information was inserted into an equation with $80 / 20$ homogeneity distribution, with a confidence interval of $95 \%$ $(z=1.96)$. The calculation pointed out the need to interview 243 college students, adding 20\% of possible sample losses during the data analysis, totaling the minimum sample of 292 college students.

Data collection was conducted in the first half of 2014 (Monday - Friday, morning, afternoon and evening). The group of researchers was composed of accordingly trained undergraduate students enrolled in the Physical Education program. In the end, 303 college students, 172 (56.8\%) freshmen, and 131 (43.2\%) seniors were evaluated.

\section{Dependent Variable}

Sleep quality

Sleep quality was analyzed by the Minisleep Questionnaire, a validated instrument for the Portuguese language by Falavigna ${ }^{15}$, composed of 10 questions with seven possible answers (never $=1$, very rarely $=2$, rarely $=3$, sometimes $=4$, often $=5$, very often $=6$ and always $=7$ ) addressing different SRD (e.g. drowsiness, insomnia, snoring etc). The sum of the 10 responses creates a numerical score ranging from 10 to 70 , classified as good sleep (score between 10 and 24 points), mild disorders (score between 25 and 27 points), moderate disorders (scores between 28 and 30 points) and severe disorders (score above 30 points). For the present study, we characterized sleep quality as good (values $<24$ points) or bad ( $\geq 25$ points). The 
questionnaire was filled out by the participants under the supervision of a researcher.

Independent variables

Previous and current physical activity

Current physical activity levels were evaluated through the Baecke questionnaire, validated for the Portuguese language by Florindo et al. $^{16}$. For the present study, information regarding the current physical activity level was extracted from the "physical activity in leisure-time" domain: i) intensity (low, moderate and vigorous), ii) weekly practice time ( $<1 \mathrm{~h} /$ week, 1-2h / 2-3h / 3-4h / >4h), and (iii) previous engagement ( $<1$ month, 1-3 months, 4-6 months, 7-9 months, $>9$ months). Individuals who reported $\geq 180$ minutes per week (3-4 hours per week) of moderate or vigorous physical activity in the past 4-6 months were classified as physically active. Individuals who did not report any physical activity and individuals who reported less than 180 minutes per week/or intensity below the established/or lower engagement time were considered inactive.

Regarding previous practice of physical activity, individuals who responded positively to the two following questions were considered physically active during childhood (7-10 years) and adolescence (11-17 years): i) "between the ages of seven and 10 years, out of school, have you been engaged in any supervised athletic activity for at least one uninterrupted year?" and ii)" between the ages of 11 and 17, out of school, have you been engaged in any supervised athletic activity for at least one uninterrupted year?". A variable was created with three categories: (I) answer "no" to both questions; (II) answer "yes" to only one question; (III) answer "yes" to both questions.

The presence of tracking of physical activity was characterized by individuals physically active individuals currently $(\geq 180$ $\mathrm{min} /$ week), during childhood and adolescence ${ }^{17}$.

\section{Sedentary behavior and body mass index}

As sedentary behavior we assessed the number of hours per week watching television, using the computer or playing video games. Individuals were classified as sedentary when reporting $\geq 22$ hours of sedentary activities per week $^{18}$. Body mass index (BMI) was calculated using the self-reported body weight $(\mathrm{Kg})$ and height $(m)$. The presence of overweight and obesity was confirmed for BMI values $\geq 25 \mathrm{Kg} / \mathrm{m}^{2}$ and $\geq 30 \mathrm{Kg} / \mathrm{m}^{2}$, respectively.

Alcohol, tobacco use, and employment

The college students were asked if they: i) consume alcohol regularly (4 or more times a week), ii) smoke regularly (4 or more times a week), iii) live with smokers, iv) are employed. For all these questions there was a possibility of yes and no answers.

\section{Statistical analysis}

Categorical variables were expressed as percentages (\%). The chi-square test analyzed the existence of associations between dependent and independent variables (the Yates correction was applied in $2 \times 2$ contingency tables). Binary logistic regression was used to construct a multivariate model in which significant associations with sleep quality (overweight, employment, smoking, and alcohol consumption) were adjusted for confounding factors (sex and age [simultaneous entry]) generating odds ratios $(\mathrm{OR})$ and $95 \%$ confidence intervals $(95 \% \mathrm{Cl})$. Statistical significance was set at $p \leq 0.05$ and all analyses were performed in BioEstat statistical software (version 5.0).

\section{RESULTS}

The sample consisted of 303 college students (122 males [40.3\%] and 181 females [59.7\%]), being $172(56.8 \%)$ freshmen and 131 (43.2\%) seniors. The students were mostly white (77.2\%), with a mean age of $22.8(5.1)$ years old and BMI of $23.5(3.9) \mathrm{Kg} / \mathrm{m}^{2}(71.3 \%$ normal, $21.8 \%$ overweight and $6.9 \%$ obese). In addition, 157 students (51.8\%) were employed, 17 (5.6\%) were smokers, 58 (19.1\%) lived with smokers, and $38(12.5 \%)$ reported consuming alcohol two or more times per week.

The prevalence of physically active students was: $25.1 \%$ currently, $74.3 \%$ in childhood, $70 \%$ in adolescence and $18.2 \%$ in all three periods (childhood + adolescence + currently). The prevalence of sedentary behavior was $50.8 \%$. Regarding sleep quality, 168 (55.4\%) was classified as bad due to the presence of SRD. The association of sleep quality and its determinants presented a significant association was found with the following variables BMI, employment, alcohol use, and smoking (Table 1). 
Table 1. Association between sleep quality and its determinants among college $(n=303$, Presidente Prudente-SP/Brazil).

\begin{tabular}{|c|c|c|}
\hline $\begin{array}{l}\text { Categorical } \\
\text { variables }\end{array}$ & $\begin{array}{c}\text { Bad Sleep Quality (score } \geq 25 \text { points) } \\
n(\%)\end{array}$ & $p^{*}$ \\
\hline Sex & & 0.814 \\
\hline Male & $122(40.3)$ & \\
\hline Female & 181 (59.7) & \\
\hline Ethnicity & & 0.063 \\
\hline White & $234(77.2)$ & \\
\hline Others & $69(22.8)$ & \\
\hline $\begin{array}{l}\text { Current Physical } \\
\text { Activity }\end{array}$ & & 0.513 \\
\hline Active & $76(25.1)$ & \\
\hline Inactive & $227(74.9)$ & \\
\hline Tracking & & 0.179 \\
\hline Active & 55 (18.2) & \\
\hline Inactive & $248(81.8)$ & \\
\hline BMI & & 0.001 \\
\hline Normal & $216(71.3)$ & \\
\hline Overweight & $66(21.8)$ & \\
\hline Obesity & $21(6.9)$ & \\
\hline Employment & & 0.03 \\
\hline Yes & $157(51.8)$ & \\
\hline No & $146(48.2)$ & \\
\hline Smoking & & 0.005 \\
\hline Yes & $17(5.6)$ & \\
\hline No & $286(94.4)$ & \\
\hline Alcohol use & & 0.001 \\
\hline Yes & $38(12.5)$ & \\
\hline No & $265(87.5)$ & \\
\hline
\end{tabular}

Notes: *chi-square test, SRD - sleep-related disorders, BMI - body mass index.

The binary logistic regression showed that overweight/obese individuals, smokers, and students consuming alcohol regularly presented $1.65,6.52$ and 1.40 times more chances of having bad sleep quality, respectively (Table 2 ).

When the multivariate model with simultaneous insertion was applied, it was observed that college students who smoke had an increased likelihood of presenting bad sleep quality when compared to non-smokers (OR $=5.42$ [1.19; 24.71]), regardless of other factors.
Moreover, overweight/obese individuals who consumed alcoholic beverages regularly presented 1.45 and 1.32 times more chances of poorer sleep quality than individuals who did not present these factors, regardless of other factors. Being employed was considered a protective factor for bad sleep quality $(O R=0.66$ [0.40; $0.98]$ ), independent of other factors (Table 3 ). 
Table 2. Association between sleep quality and BMI, smoking, alcohol consumption and employment among college students ( $n=303$, Presidente Prudente-SP/Brazil).

\begin{tabular}{|c|c|c|}
\hline Variables & $\begin{array}{c}\text { Chi-square } \\
\text { p }\end{array}$ & $\begin{array}{c}\text { Binary Logistic Regression } \\
\text { Gross OR }(95 \% \mathrm{Cl})^{*}\end{array}$ \\
\hline BMI & 0.001 & \\
\hline Normal & & 1.00 \\
\hline Overweight/Obesity & & $1.65(1.35 ; 2.32)$ \\
\hline Employment & 0.030 & \\
\hline No & & 1.00 \\
\hline Yes & & $0.61(0.38 ; 0.90)$ \\
\hline Smoking & 0.005 & \\
\hline No & & 1.00 \\
\hline Yes & & $6.52(1.46 ; 29.03)$ \\
\hline Alcohol use & 0.001 & \\
\hline No & & 1.00 \\
\hline Yes & & $1.40(1.16 ; 1.69)$ \\
\hline
\end{tabular}

Notes: OR - odds ratio 95\% confidence interval; *model adjusted by sex and age; BMI - body mass index.

Table 3. Multivariate model expressing the associations between sleep quality, BMI, alcohol use, smoking and employment among college students ( $n=303$, Presidente Prudente-SP/Brazil).

\begin{tabular}{lcc}
\hline Variables & $\begin{array}{c}\text { Chi-square } \\
p\end{array}$ & $\begin{array}{c}\text { Binary Logistic Regression } \\
\text { Adjusted OR }(95 \% \mathrm{Cl})^{*}\end{array}$ \\
\hline $\begin{array}{l}\text { BMI } \\
\quad \text { Normal }\end{array}$ & $\mathbf{0 . 0 0 1}$ & 1.00 \\
$\quad$ Overweight/Obesity & & $1.45(1.20 ; 2.12)$ \\
$\begin{array}{l}\text { Employment } \\
\text { No }\end{array}$ & $\mathbf{0 . 0 3 0}$ & 1.00 \\
$\quad$ Yes & & $0.66(0.41 ; 0.98)$ \\
$\begin{array}{l}\text { Smoking } \\
\text { No }\end{array}$ & $\mathbf{0 . 0 0 5}$ & 1.00 \\
$\quad$ Yes & & $5.42(1.19 ; 24.71)$ \\
Alcohol use & & 1.00 \\
$\quad$ No & 0.001 & $1.32(1.08 ; 1.603)$ \\
Yes & & \\
\hline
\end{tabular}

Notes: OR - odds ratio $95 \%$ confidence interval, *model adjusted by sex, age, BMI, labor activity, alcohol and tobacco use (Hosmer's and Lemeshow test with $\mathrm{p}=0.167$ ). $\mathrm{BMI}$ - body mass index.

\section{DISCUSSION}

The present study verified the quality of sleep as well as its determinants among college students of a private university in Brazil and identified that higher BMI, smoking and regular alcohol consumption are associated with the occurrence of SRD.

Approximately half of the sample showed sedentary behaviors, whereas a quarter were considered physically active. Studies that assessed sedentary behavior and practice of physical activities among college students indicate that this behavior is common in this population $^{19}$, with a large percentage of them not reaching a minimum of 150 minutes of physical activity per week ${ }^{20}$. These findings are similar to the youth population, with data indicating that adolescents spend four or more hours per day on sedentary behavior ${ }^{21}$. Therefore, considering that sedentary behavior and physical inactivity are associated with sleep quality ${ }^{22}$, the high prevalence of both factors in the present sample may explain the high percentage (55.4\%) of individuals with bad sleep quality.

Are also connected with bad sleep quality were overweight/obesity ${ }^{23}$, alcohol and tobacco 
use ${ }^{24,25}$. Studies conducted with overweight and obese individuals indicate a higher likelihood of developing $\mathrm{SRD}^{23}$. The association of overweight/obesity with duration and quality of sleep has been observed since childhood ${ }^{26}$ and can be explained by the important relationship between sleep quality and metabolic hormones, with the reduction of hours of sleep associated with decreased leptin and increased ghrelin, changes that propitiate the individual to a state of overweight and obesity ${ }^{27}$. Likewise, as observed above, the literature does not present a clear causal relationship between these variables, and thus, caution is necessary when analyzing these results.

Similarly to our findings, a US study evaluating college students (mean age 19 years old) from several states found that alcohol consumption was associated with poorer quality of sleep ${ }^{28}$. Alcohol consumption causes a decrease in sleep-onset latency, followed by a deep sleep phase and another immediately after disturbed sleep ${ }^{29}$, and may even alter the circadian rhythm ${ }^{24}$, which substantially impairs sleep quality.

Regarding the association between sleep quality and smoking, the scientific literature states that tobacco use causes changes in sleep behavior, such as increased latency, decreased total sleep time, and still sleep interrupted several times at night ${ }^{30}$. Additionally, smoking is an important risk factor for the development of chronic diseases, one of the leading cause of preventable deaths ${ }^{31}$. However, even though the harmful effects of smoking are widely clear, the National Survey by Household Samples ${ }^{32}$ carried out in 2008 estimated that 24.6 million people (17.2\%) smoked any tobacco product, the prevalence of smoker higher among men (21.3\%) when compared to women (13.1\%). In 2013, the prevalence of smokers continued high (15\%, 21.9 million people) ${ }^{33}$.

Interestingly, we found that college students with a job were less likely to have SRD when compared to unemployed students. A study conducted in Germany with more than 9,000 adults aged 18 to 80 years old reported that workers presented better sleep quality, which was assessed by total sleep time, latency time sleep disorders, sleep disturbances, and the use of sleeping medications ${ }^{34}$. However, it is important to point out that sleep quality can be altered if the workload is strenuous, leading to a decrease in total sleep hours ${ }^{35}$.
As the main limitation of the study, we can highlight the probability of reverse causality due to the cross-sectional design with retrospective characteristics. In addition, the sample only included students from one university in Brazil, and caution is necessary when making inferences to other groups of college students. We also point out the possible heterogeneity of this sample, since they were not considered information about the study period (morning or night), nor information about there were socioeconomic status differences between the periods, information that could have altered the results.

In conclusion, that college students presented a high prevalence of bad sleep quality, having as determinants of this outcome alcohol consumption, smoking, overweight, and obesity. On the other hand, employment showed to be a protective factor for poor sleep quality. These results imply the need for educational and health promotion programs for college students, aiming to reduce risk factors/behaviors, as well as to improve the quality of sleep and academic performance.

\section{ACKNOWLEDGMENTS}

This study was supported by the Coordenação de Aperfeiçoamento de Pessoal de Nível Superior (CAPES).

\section{CONFLICT OF INTEREST}

The authors declare that there is no potential conflict of interest that could interfere with the impartiality of this scientific work.

\section{REFERENCES}

1. Neves GSM, Giorelli AS, Florido P, Gomes MM. Transtornos do sono: visão geral. Rev Bras Neurol. 2013; 49(2):57-71.

2. Watson NF, Badr MS, Belenky G, Bliwise DL, Buxton OM, Buysse $D$ et al. Recommended amount os sleep for a healthy adults: a joint consensus statement of the american academy of sleep medicine and sleep research society. Sleep. 2015;38(6):843-844.

DOI:

https://doi.org/10.5665/sleep.4716

3. Luyster FS, Strollo JR. PJ, Zee PC, Walsh JK. Sleep: a health imperative. Sleep. 2012;35(6)72734. DOI: https://doi.org/10.5665/sleep.1846 
4. Petrov ME, Lichstein KL, Baldwin C. Prevalence of sleep disorders by sex and ethnicity amongolder adolescents and emerging adults: Relations to daytime functioning, working memory and mental health. I Adolesc. 2014;37:587-597.

DOI: https://doi.org/10.1016/j.adolescence.2014.04.0 $\underline{07}$

5. Zanuto EA, Lima MCS, Araujo RG, Silva EP, Anzolin CC, Araujo MYC, Codogno JS, Christofaro DGD, Fernandes RA. Distúrbios do sono em adultos de uma cidade do estado de São Paulo. Rev Bras Epidemiol. 2015;18(1):42-53. DOI: https://doi.org/10.1590/1980-

$\underline{5497201500010004}$

6. Cappuccio FP, Miller MA. Sleep and cardiometabolic disease. Curr Cardiol Rep. 2017;19:110. DOI: https://doi.org/10.1007/s11886-017-0916-0

7. Becker SP, Jarrett MA, Luebbe AM, Garner AA, Burns GL, Kofler MJ. Sleep in a large, multiuniversity sample of college students: sleep problem prevalence, sex differences, and mental health correlates. Sleep Health. 2018;4:174-81. DOI: https://doi.org/10.1016/i.sleh.2018.01.001

8. Moraes M, Laat EF, Lara L, Leite GT. Consumo de álcool, fumo e qualidade de vida: um comparativo entre universitários. Cinergis. 2010;11(1):85-94.

9. Van Reen E, Roane BM, Barker DH, McGeary JE, Borsari B, Carskadon MA. Current alcohol use is associated with sleep patterns in first-year college students. Sleep. 2016;39(6):1321-1326. DOI: https://doi.org/10.5665/sleep.5862

10. Pope L, Hansen D, Harvey J. Examining the weight trajectory os college students. J Nutr Educ Behav. 2017;49(2):137-141. DOI: https://doi.org/10.1016/i.jneb.2016.10.014

11. Downes L. Physical activity and dietary habits of college students. JNP. 2015;11(2):192-198. DOI:

https://doi.org/10.1016/j.nurpra.2014.11.015

12. Cai GH, Theorell-Haglöw J, Janson C, Svartengren M, Elmståhl S, Lind L, Lindberg E. Insomnia symptoms and sleep duration and their combined effects in relation to associations with obesity and central obesity. Sleep Med.
2018;46:81-87.

DOI:

https://doi.org/10.1016/i.sleep.2018.03.009

13. Dolezal BA, Neufeld EV, Boland DM, Martin JL, Cooper CB. Interrelationship between sleep and exercice: a systematic review. Adv Prev Med. 2017.

DOI:

https://doi.org/10.1155/2017/1364387

14. Haile YG, Alemu SM, Habtewold. Insomnia and its temporal association with academic performance among university students: a crosssectional study. BioMed Res Int. 2017. DOI: https://doi.org/10.1155/2017/2542367

15. Falavignia A, Teles AR, Braga GL, Barazzetti DO, LazzarettiL, Tregnago AC. Instrumentos de avaliação clínica e funcional em cirurgia da coluna vertebral. Coluna/Columna. 2011;10(1):62-67. DOI: $\quad$ https://doi.org/10.1590/S1808$\underline{18512011000100012}$

16. Florindo $A A$, Latorremdo $R$, Jaime $P C$, Tanaka $T$, Zerbini CA. Methodology to evaluation the habitual physical activity in men aged 50 years or more. Rev Saúde Pública. 2004;38(2):307-14. DOI: $\quad$ https://doi.org/10.1590/S0034$\underline{89102004000200022}$

17. Fernandes RA. Prática da atividade física e prevalência de doenças cardio-metabólicas no estado de São Paulo. [Tese]. Doutorado no Instituto de Biociências, UNESP. Rio Claro, 2011.

18. Christofaro DGD. Excesso de peso em adolescentes: associações com características próprias e de seus pais ou responsáveis. [Tese]. Doutorado no Programa de Pós-Graduação Stricto Sensu em Saúde Coletiva da Universidade Estadual de Londrina, UEL. Londrina, 2012.

19. Musaiger AO, Awadhalla MS, Al-Mannai M, AlSawad M, Asokan GV. Dietary habits and sedentary behaviors among health science university students in Bahrain. Int J Adolesc Med Health. 2015;29(2). DOI: https://doi.org/10.1515/ijamh-2015-0038

20. Downes L. Physical Activity and dietary habits of college students. JNP 2015;11(2):192-98e2. DOI:

https://doi.org/10.1016/i.nurpra.2014.11.015 
21. Hallal PC, Andersen LB, Bull FC, Guthold R, Haskell W, Ekelund U. Global physical activity levels: surveillance progress, pitfalls, and prospects. Lancet. 2012;380:247-57. DOI: https://doi.org/10.1016/S0140-6736(12)60646-1

22. Zanuto EAC, Christofaro DGD, Fernandes RA. Sleep quality and its associations with leisuretime exercise and excess weight among civil servants. Rev Bras Cineantropom Desempenho Hum. 2014;16(1):27-35. DOI: https://doi.org/10.5007/1980$\underline{0037.2014 v 16 n 1 p 27}$

23. Vasconcelos HCA, Fragoso LVC, Marinho NBP, Araújo MFM, Freitas RWJF, Zanetti ML, Damasceno MMC. Correlação entre indicadores antropométricos e a qualidade do sono de universitários brasileiros. Rev Esc Enferm USP. 2013;47(4):852-9.

DOI:

https://doi.org/10.1590/S0080-

$\underline{623420130000400012}$

24. Hasler BP, Soehner AM, Clark DB. Sleep and circadian contributions to adolescent alcohol use disorder. Alcohol 2015;49:377-87. DOI: https://doi.org/10.1016/i.alcohol.2014.06.010

25. Liu J, Lee I, Wang C, Chen K, Lee C, Yang Y. Cigarette smoking might impair memory and sleep quality. J Formos Med Assoc. 2013;112:28790.

DOI:

https://doi.org/10.1016/j.jfma.2011.12.006

26. Zhang J, Jin X, Yan C, Jiang F, Shen X, Li S. Short sleep duration as a risk factor for childhood overweigth/obetity: a large multicentric epidemiologic study in China. Sleep Health. 2015;1:184-90. DOI: https://doi.org/10.1016/j.sleh.2015.06.001

27. Omiside A, Buxton OM, Rusak B. Impact of acute sleep restriction on cortisol and leptin levels in young women. Physiol Behav. 2010;99:651-56. DOI: https://doi.org/10.1016/i.physbeh.2010.01.028

28. Kenny SR, LaBrie JW, Hummer JF, Pham AT. Global sleep quality as a moderator of alcohol consumption and consequences in college students. Addict Behav. 2012;37:507-12. DOI: https://doi.org/10.1016/j.addbeh.2012.01.006
29. Ebrahim IO, Shapiro CM, Williams AJ, Fenwick PB. Alcohol and sleep I: effects on normal sleep. Alcohol Clin Exp Res. 2013;37(4):539-49. DOI: https://doi.org/10.1111/acer.12006

30. Jaehene $A$, Unbehaun $T$, Feige $B$, Lutz UC, Batra A, Riemann D. How smoking affects sleep: a polysomnographical analysis. Sleep Med. 2012;13(10):1286-92. DOI: https://doi.org/10.1016/j.sleep.2012.06.026

31. WHO. World Health Organization. WHO report on the global tobacco epidemic, 2011: warning about the dangers of tobacco. Geneva: WHO, 2011.

32. Pesquisa Nacional por Amostra de Domocílos (PNAD) 2008. Tabagismo. Rio de Janeiro: IBGE, 2009.

33. Pesquisa Nacional de Saúde (PNS). Percepção do estado de saúde, estilos de vida e doenças crônicas. Brasil, Grandes Regiões e Unidades da Federação. Rio de Janeiro: IBGE; 2014.

34. Andreas $H$, Glaesmer $H$, Brahler E, Loffler $M$, Engel C, Enzenbach C, Hegerl U, Sander C. Sleep quality in the general population: psychometric properties of the pittsburgh sleep quality index, derived from a german community sample of 9284 people. Sleep Med. 2016. DOI: https://doi.org/10.1016/i.sleep.2016.03.008

35. Katharine RP. Age and work environment characteristics in relation to sleep: Additive, interactive and curvilinear effects. Appl Ergon. 2016;54:41-50. DOI: https://doi.org/10.1016/i.apergo.2015.11.009 